\title{
Creative Writing for Language, Content and Literacy Teaching
}

\author{
María Teresa Fleta Guillén \\ Alcalá de Henares University, Modern Philology Department \\ 28801 Alcalá de Henares, Madrid, Spain \\ E-mail: tfleta@perlaunion.es \\ María Luisa García Bermejo \\ Universidad Complutense, School of Education \\ 28040 Madrid, Spain \\ Tel: 34-913-946-281Ｅ-mail: mlgarber@edu.ucm.es
}

Received: November 22, 2011

Accepted: November 28, $2011 \quad$ Published: December 1, 2011

doi:10.5539/ies.v4n5p39

URL: http://dx.doi.org/10.5539/ies.v4n5p39

\begin{abstract}
This paper reports on pedagogies that promote language, content and literacy in English by stimulating learners' creativity. The starting point to promote creativity among learners was music and art. There seems to be a natural connection between music, language and thinking which suggests that incorporating musical experiences into daily instruction results in creative thinking. By being exposed to music and art, learners of different ages and from different language contexts developed visualization abilities and invented stories. According to many authors, stories are excellent vehicles for teaching and learning because they contain all the ingredients from which learners can benefit. The learners in this study moved from listening to music, to the word and sentence levels, to finally telling their stories in English, and the stories the learners created proved to be a vehicle for internalizing language and for literacy development.
\end{abstract}

Keywords: Creative writing, Story making, Storytelling, Oracy and literacy

\section{Introduction}

In many countries around the world, children start learning English as an additional language (L2) at Pre-school level, and in order to develop competent bilingual skills, the schools need to provide effective educational programs that create the necessary conditions under which teaching/learning in the second language takes place.

The methodologies presented in this paper can be adapted to child and adult learners and can also be adaptable to different settings. The same teaching techniques were presented to children at school and to student teachers at university with a twofold purpose: to create a rich linguistic environment, and to promote creativity and collaborative learning. As many authors point out, storytelling is an old form of teaching and stories are excellent vehicles for content/language learning because they contain all the ingredients from which learners can benefit (Gardner, 1994; Garvie, 1990; Moon, 2000; Wright, 2000).

One of the underlying reasons to experiment with child learners was to explore different approaches to language teaching bearing in mind the learners' age and taking into consideration what children are like and what children enjoy in the early years, particularly children between 3 and 12 years of age. The main aim to carry out the same teaching activities at university level was to provide student teachers with specialised training and with useful resources in Primary methodology. Teachers need in-service opportunities to write and read creatively themselves, and sessions on creative training to foster a better understanding of teaching techniques and to be better able to put them into practice in class.

From the linguistic point of view, story making and storytelling proved to be excellent tools to improve the four skills in English L2 because the learners moved from a one-word level to the sentence level, to finally telling their stories in English. From the creative point of view, the learners developed ideas in their own way and, from the pedagogical perspective, this project-based learning helped the students to work on cooperative learning techniques. 
In the end, the stories created by both types of learners reflected the manner in which they had internalized language and content after having carried out activities specifically designed to put their multiple intelligences at work.

This paper is organized as follows: firstly, background information is provided on the use of the stories as a vehicle for teaching and learning, on the theory of Multiple Intelligences (MI) and on creative and collaborative learning. Secondly, the creative writing project is described. Thirdly, the results and the conclusions are presented. Finally, the chief pedagogical implications are drawn.

\section{Literature Review}

Storytelling is a very old form of teaching, and during story time session, teachers and pupils share language, content and feelings. Children from all languages are familiarised with the format of stories, which is common to all languages and is based on the fairy tale structure. Traditionally, storytelling has been used to entertain and to educate children, and stories are considered to be excellent vehicles for language teaching and learning by various authors. Cameron (2001) provides an example that clarifies this point:

Children listening to a story told in a foreign language from a book with pictures will understand and construct the gist, or outline meaning, of the story in their minds. Although the story may be told in the foreign language, the mental processing does not need to use the foreign language, and may be carried out in the first language or in some language-independent way, using what psychologists call "mentalese". (p.40)

Stories can be used with different age and ability groups and provide all students (child and adult learners) with opportunities for vocabulary building and for developing the four skills. Reading books in class helps learners to understand, interact, write and read texts in the $\mathrm{L} 2$ and also to develop positive attitudes towards the target language. When foreign language learners are read picture stories, they get the meaning of the words from the book illustrations and through the context, and they are also introduced to the book language (to spacing and punctuation, and to the fact that books are read from left to right and from top to bottom). Besides, as the language in stories is contextualized, it provides meaning and helps in the comprehension of the texts. Garvie (1990) underlines this point further:

Remember that the growth-points for literacy are to be found in oracy, and the more the children have been stimulated to listen and speak by a story, the more easily the skills of reading and writing can be developed as the story carries the children along. (p.105)

Children are familiarized with stories, their structure, and with the formulaic language that goes with them in their mother tongue since they are little: the beginning of a story, which includes the characters and the settings; the middle of the story in which the conflict and the action occur; and the end of the story, which is dedicated to the resolution of the problem. Child L2 learners are familiarized with expressions such as Once upon a time..., they lived happily ever after or and this is the end of the story, as they have heard this formulaic language while listening to stories in their mother tongue. Moreover, stories are adaptable to the learners' age and language level, and children can benefit from listening to stories and from creating their own stories.

The language used in the stories is not referential as in textbooks, since stories contain vocabulary, intonation, grammatical structures and formulaic language within a context. The language in stories is representational and the characters think, interact, cry, shout or smile as in real life. When children listen to stories, they have access to the patterns of the language and, at the same time, they develop an understanding of the plot; hence, stories should be considered an essential part of language teaching and learning because they give the learners experience with language and because they make indirect and unconscious language learning meaningful. When teachers use stories in their classrooms, they are offering their students multiple opportunities to learn contents and ways of being, and to improve the mastery of communication skills (listening, speaking, reading and writing). Table 1 shows how literacy and oracy are interlinked and how teachers can help pupils learn to listen, to write, to read and to speak by planning story creative writing as a stimulating project. As Mason and Krashen (2004) state, stories offer learners multi-sensory experiences and opportunities for holistic learning, through which many different learning styles can be catered to: "It is our sense of enjoyment, excitement, and emotional involvement that is a necessary condition for learning, and using literature in the classroom can provide the content base for the magic" (p.184).

The teaching techniques presented in this paper were developed within this pedagogical framework and were thought out to help learners in their task of learning language and content through the means of writing, reading, telling and listening to stories in English L2, bearing in mind that every learner has a different style of learning and that by linking thinking and learning, language learners can become creative and can communicate in the L2. In 
other words, child and adult learners can benefit from story making and from storytelling because they create opportunities for real communication.

\subsection{Multiple Intelligence Theory}

Following the Multiple Intelligence theory (MI) developed by Gardner (1983), we are all thought to possess different avenues for learning (Linguistic, Mathematical, Spatial, Musical, Kinaesthetic, Interpersonal, Intrapersonal and Naturalistic) and each individual is thought to possess a combination of these intelligences and the capacity to develop all of these intelligences and to learn by using them. Table 2 illustrates the Multiple Intelligences proposed by Gardner.

Traditionally, learning has taken place via textbooks, teachers' explanations, and paper and pencil tests and only the linguistic and logical-mathematical abilities have been assessed. Nowadays, all children are thought to have multiple strengths and the teacher's role is to adjust their instructional strategies in order to allow students to use their strengths and also to show what they have learned. As Gardner puts it (1995): "We are not all the same, we do not all have the same kinds of minds, and education works most effectively for most individuals if [...] human differences are taken seriously" (p. 208).

Thus, teachers who offer their students a variety of activities will be contributing to the development of their students' multiple intelligences. The rationale behind using the MI approach in this project to promote language and content in English was multifold: to help children in Primary education become creative individually; to learn through a combination of visual, auditory, kinaesthetic, interpersonal, mathematical, linguistic and intrapersonal styles; and to create a setting in which student teachers could experiment on collaborative creative writing in teams.

\subsection{Creativity in the Classroom}

In general terms, education has focused more on the ability to recall and retell stories accurately rather than on preparing children to become creative themselves. In a different vein, Wright (2006) considers that by listening to stories and to fairy tales, children can increase the ability to visualise and to develop their imagination: "Creativity is making something new, or a new version of something [...], it is also when you devise activities and make materials $[\ldots]$, making new connections is what creativity is" (p.17).

The idea of presenting these teaching techniques to future teachers was to provide them with tools for their professional development and came up during the preparation of three workshop sessions on story time, story making and storytelling. As Met (1999) suggests: "When students learn content through a new language, they need a variety of instructional materials and teachers may need to develop their own materials. Teachers may need in-service opportunities to write and read creatively themselves" (p.35).

By establishing sessions on creative training, we were preparing future teachers to have a better understanding of teaching techniques and to be better able to put them into practice in class.

Child learners see teachers in the classroom as models; thus, teachers must be prepared to go through the process of creative writing themselves and have the chance to model the courage of being creative, of knowing what the difficulties are, and of what it feels like to go through the process.

\subsection{Collaborative Learning}

The term collaborative learning refers to a teaching method in which students achieve an academic goal in pairs or in small groups and in which the students go through a series of phases while working together towards achieving the final goal. According to Larsen-Freeman (2000), cooperative or collaborative learning essentially involves students learning from each other in groups.

Using collaborative learning is an alternative of making learning more interesting than using only textbooks. Learners get involved in the learning process, they create the characters for their stories in groups, and they establish contexts, problems and resolutions of the problems. Similarly, when children listen to stories in big groups, they ask questions and discuss with their teachers the characters, plots, or settings; they experience face-to-face interaction, and this kind of interaction helps them to remember the story to a greater extent. As Johnson, D., Johnson, R., and Smith (1991) put it, by working in groups, students exchange ideas, engage in discussions and make decisions which help them become critical thinkers:

Cooperative learning is indicated whenever the goals of learning are highly important, mastery and retention are important, the task is complex or conceptual, problem solving is desired, divergent thinking or creativity is desired, quality of performance is expected and higher level reasoning strategies and critical thinking are needed. (p.40) 
The rationale behind using collaborative learning techniques in this project was to provide student teachers with tools for their professional development. As we mentioned above, active learners learn more by doing something than by merely watching and listening to how others do it.

\subsection{Graphic Organizers}

Graphic Organizers (GO) are very useful guides for thinking, learning and remembering. They are visual aids that can be used in all classroom areas to organize ideas and to help learners to activate previous knowledge. GOs are also very helpful for teachers; they can be filled in by the teacher or by the students and used individually, in pairs or with the whole class. When they are used with the whole class, learners share ideas, interact and can see what they personally think and what others think. Examples of GOs include, among others: flow charts, Venn diagrams, network trees, cycle charts, story maps, or story organizers. Table 3 presents the flow chart used in the story creative writing project.

There are learners who find it easier to organize information with the visual support that the graphic organizers provide than with linear information; and there are learners who find it easier to show what they know than to say it because they see what they think first. Thus, GOs are ideal tools to help planning, to explore what learners know, to help students to remember more, and also for predicting and for evaluating. Using charts in class is a good exercise for writing and for classifying, and it is particularly useful for pre-writing activities. By incorporating a flow chart in the creative story writing projects at school and at university, the learners were able to link visual support, language, content and thinking.

\section{The Creative Writing Project}

The initial stimulus to promote creativity among learners was music and art. According to Gardner (1983), musical intelligence develops first and runs parallel to linguistic intelligence. There seems to be a natural connection between music, language and thinking which suggests that incorporating musical experiences into daily instruction results in creative thinking and has multiple benefits: to improve listening and oral skills development, to extend vocabulary and to improve attention span and memory.

The music used for inspiration was by Grieg (Peer-Gynt Suite: In the Hall of the Mountain King and March of the Dwarfs Op.54/3), Vivaldi (Summer, Presto) and Brahms (Lullaby, Waltz in A flan major Op. 39/15); and also the picture "The Scream" by Munch and Symphony No.2: Misterious Mountain, Op.132,III. Andante Expressivo by Hovhaness. Both music and art were used as the starting point for creativity and to foster thinking and self-expression.

\subsection{Participants}

As Table 4 shows, three groups of learners participated in the creative writing project. One of the groups of children taking part in the pedagogical experience was from a bilingual school (British Council School of Madrid). This school takes children from 3 to 18 years of age, $98 \%$ of whom are native speakers of Spanish and in it, language and content are equally important and the mastery of academic objectives is considered as important as the development of proficiency in the target language. The children participating in the project were in Year 2, 7-8 years of age, and had been learning English for four years. The entire writing project took place over a period of 6 months during one academic year (from November to May).

The other group of children was from the Bosque School in Madrid, where CLIL methodology has been implemented in Primary education since 2005. This school teaches part of the Spanish curriculum, specifically Science, Arts and Crafts, and Physical Education, through English from ages 5 to 12. The experience took place in the first year of Primary (ages 6 to 7) during two sessions of 45 minutes each.

The adult learners who were introduced experientially to the English L2 teaching techniques were students from the School of Education at the Madrid Complutense University (UCM) and they were enrolled in the pilot subject English Literature and its Didactics. All of them were studying to become English specialists at Primary level. The creative writing experience was the last activity they had after having been exposed to the above-mentioned workshops on stories. The fifty-eight students who experienced the methodology were in their first, second and third year of the degree and their age ranged from 18 to 38 . They worked individually and in groups during a session of an hour and a half, and time was allotted for each task.

\subsection{Project Description}

Phase I: Visualization

The three groups of learners were invited to listen to a piece of music, imagine a character and draw it. In the case of one group of student teachers, they were also asked to watch a piece of art while listening to the music. Then, they 
were asked to think of words to describe the picture they had visualized. The purpose of this activity was to work on Musical, Linguistic and Visual-Spatial intelligences, to tap into the learners' creativity and to use visualization as a learning strategy. For this part of the project, the learners worked individually.

\section{Phase II: Movement}

At this stage, the group of children from the bilingual school were asked to express their emotions and to use different types of movement by moving freely to the music in the gym, as they thought their character would move and use different types of movements. The purpose of this activity was to review quality of movement skills, to reinforce vocabulary in English and to develop facets of the kinaesthetic and musical intelligences. Student teachers in groups of three or four worked on brainstorming associations, talked about their characters and decided on one or more characters about which to write the story. The purpose of this phase was to work on their intrapersonal and linguistic intelligences.

Phase III: Drafting

During this phase, the learners, individually (children) or in groups (student teachers) thought of a setting and a title for the story, and created lists of words. This was a good opportunity to practice vocabulary, and making lists of words helped those child learners who had difficulties for writing. The purpose of this activity was basically to work on linguistic intelligence.

\section{Phase IV: Flow Chart and Interaction}

Later, the learners created a story map (see Table 3 ) and integrated the information of the key incidents into the flow chart, which consisted of six spaces: one for the beginning of the story; three for the middle of the story where the conflict or problem was indicated; and two spaces for the resolution of the problem. By incorporating a flow chart in the story writing, the learners were able to link visual support, language, content and thinking. The purpose of using flowcharts was to help children use space and to memorize better the story and sequence it.

The group of child learners from the bilingual school interacted in pairs and they told their peers. The purpose for interacting was to give children the opportunity to work on their interpersonal, intrapersonal and linguistic intelligences.

\section{Phase V: Editing (Writing, Illustrating and Book Making)}

All learners worked on the text and the illustrations of their books. They transferred the information from their skeleton notes and from the flow charts into a book format. They designed and decorated a cover page and wrote a blurb for the back of the book. The book format was based on the fairy tales structures and the six spaces of the flow chart corresponded to the six pages of the book. The purpose of this part of the project was to work on linguistic and spatial intelligences and, more specifically, to encourage children to take responsibility for their own writing.

\section{Phase VI: Storytelling}

All learners had the opportunity to read their stories aloud and to talk about their pictures in class and, by doing so, to work on storytelling skills. In order to facilitate language learning and to offer future teachers the possibility of putting into practice strategies to write and tell stories, they also presented their stories to the class. The usefulness of this pedagogical experience was reflected in the comments students made in the feedback forms at the end of the experience According to the student teachers, music was a starting point and a complement for the rest of the activities. Music triggered their imagination and creativity and helped them in the process of creating and visualizing their characters and their stories. Working in small groups gave future teachers the opportunity to contrast ideas and points of view with their peers, to interact in English and to create a story collaboratively.

\section{Conclusion and Pedagogical Implications}

As young learners' teachers know, children learn words easily but they forget them easily, too; thus, providing learners with memorable strategies will foster remembering new words. The innovative pedagogies described in this paper proved to be memorable and gave the learners the chance to create their own characters and to express their own messages in their stories and by doing so, the words they were using were easily retrieved from memory. Going through the different phases made learning active and helped the learners internalise language in an unconscious manner. Story making and storytelling were excellent vehicles for internalizing English language patterns, for the development of the four skills and for the presentation of English L2 in class. From the linguistic point of view, the learners moved from listening to music, to the sentence level, to finally telling their stories in English.

By participating in the process of making books and telling stories to an audience, young and adult learners were encouraged to interact and to do as much as they could by themselves, individually or in groups. The learners made thinking visible through illustrating, writing and telling their stories, thereby exploring stories from the point of view 
of the story maker, the storyteller and the listener. Learning English through music, movement and art stimulated the learners' multiple intelligences and helped them develop visualization abilities and create a rich linguistic environment in which language was internalized. Therefore, the music that teachers consider adequate for each occasion and for each particular group of learners can become a teaching/learning resource and an important foundation for literacy.

The flow charts proved to be ideal vehicles to predict, to sequence and to organise the stories. The different ways of showing information through the graphic organizers helped the learners make thinking visible, something positive as for some learners visual information is more memorable. Thus, selecting the best type of graphic organizer can foster memory, understanding and concept development and can help learners interpret the information.

Teachers need in-service opportunities to write and read creatively and, by tracking the learning process, the student teachers were able to try ideas out and to investigate how children learn before practicing teaching. At the end of the project, they had a better understanding of teaching techniques and of how to put them into practice in class because they had put theory into practice first-hand.

Summing up, these pedagogies could be scheduled for creative story writing in the English L2 classroom and they could also be used for creative writing in the mother tongue or any other additional languages. In addition, they could also be employed to make cross-curricular links to other subject matters for content teaching.

\section{References}

Cameron, L. (2001). Teaching languages to young learners. Cambridge: Cambridge University Press. http://dx.doi.org/10.1017/CBO9780511733109

Gardner, H. (1983). Frames of mind: The theory of multiple intelligences. New York: BasicBooks.

Gardner, H. (1994). The arts and human development: A psychological study of the artistic process. New York: BasicBooks.

Gardner, H. (1995). Reflections on Multiple Intelligences: Myths and Messages. Phi Delta Kappan, 77 (3), 200-209

Garvie, E. (1990). Story as a vehicle: Teaching English to young children. Clevedon: Multilingual Matters.

Johnson, D., Johnson, R., \& Smith, A. (1991): Active learning: Cooperation in the college classroom. Edina, MN: Interaction Book Company.

Larsen-Freeman, D. (2000). Techniques and principles in language teaching. (2nd edition). Oxford: Oxford University Press.

Mason, B., \& Krashen, S. (2004). Is Form-Focused Vocabulary Teaching Worthwhile? RELC Journal, 35 (2), 179-185. http://dx.doi.org/10.1177/003368820403500206

Met, M. (1999). Content-based instruction: Defining terms, making decisions (NFLC Reports). Washington, DC: The National Foreign Language Center. [Online] Available: http://www.carla.umn.edu/cobaltt/modules/principles/decisions.html (October 30, 2011).

Moon, J. (2000). Children learning English. Oxford: Macmillan-Heinemann.

Wright, A. (2000). Stories and Their Importance in Language Teaching. Humanising Language Teaching, 2 (5). [Online] Available: http://www.hltmag.co.uk/sep00/martsep002.rtf (October 30, 2011).

Wright, A. (2006). Being Creative: Things I Find Useful. Cats: The IATEFL Young Learners Publication. 
Table 1. Developing oracy and literacy

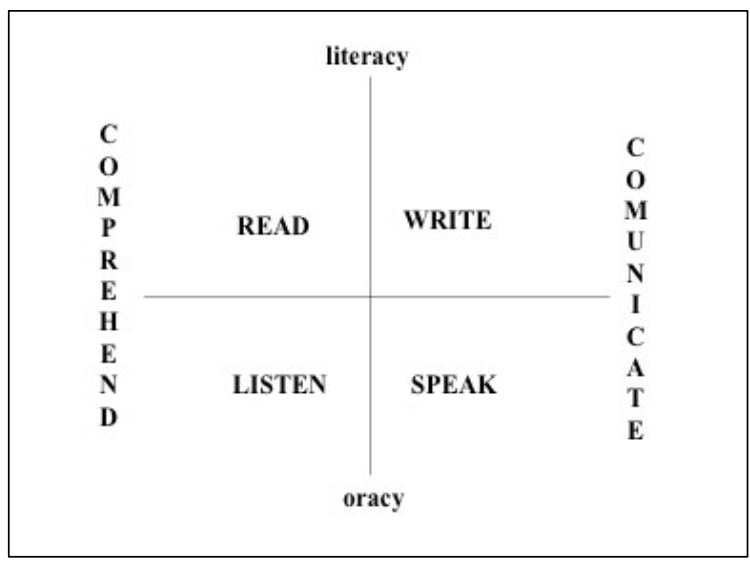

Table 2. Multiple Intelligences

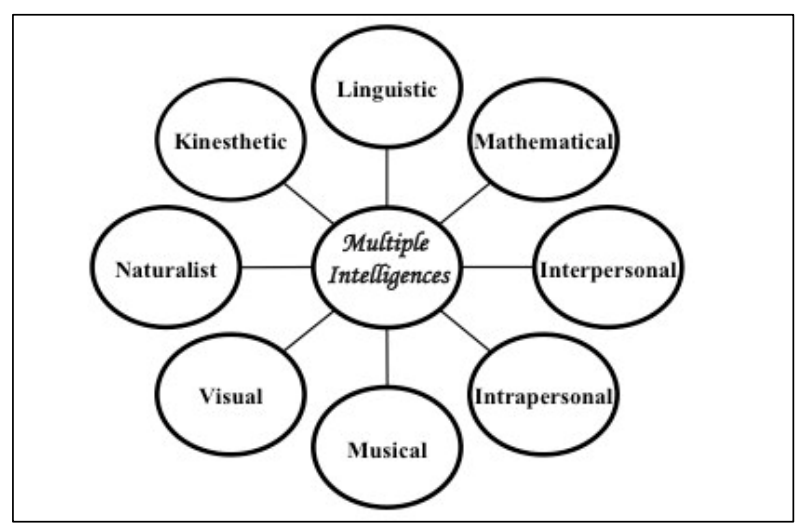

Table 3. Story Organizer

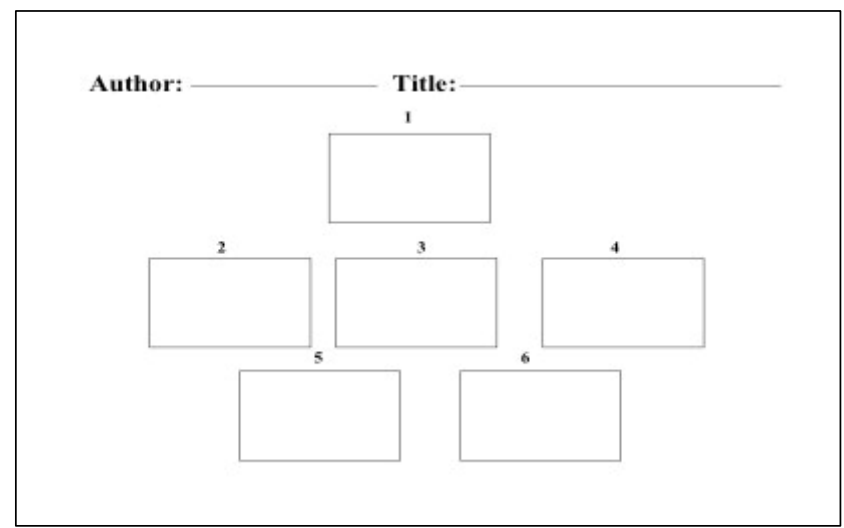


Table 4. Breakdown of the participants

\begin{tabular}{|c|c|c|c|}
\hline Place & $\begin{array}{c}\text { Bilingual School } \\
(\mathrm{BCS})\end{array}$ & $\begin{array}{c}\text { CLIL School } \\
\text { (Bosque) }\end{array}$ & $\begin{array}{c}\text { University } \\
(\mathrm{UCM})\end{array}$ \\
\hline Participants & 21 & 20 & 58 \\
\hline Age & $7-8$ & $6-7$ & $18-46$ \\
\hline Stories & 21 & 20 & 22 \\
\hline Time & A Semester & $45^{\prime}$ Session & $1 \mathrm{~h} 30^{\prime}$ Session \\
\hline
\end{tabular}

